\title{
A closer look at racial differences in the reporting of self-assessed health status and related concepts in South Africa
}

\author{
Authors: \\ Gerard Boyce ${ }^{1}$ \\ Geoff Harris ${ }^{1}$ \\ Affiliations: \\ ${ }^{1}$ School of Economics and \\ Finance, University of \\ KwaZulu-Natal, South Africa \\ Correspondence to: \\ Gerard Boyce \\ Email: \\ gdboyce@yahoo.com \\ Postal address: \\ PO Box 54001, Durban 4000 \\ South Africa \\ Dates: \\ Received: 22 Apr. 2010 \\ Accepted: 18 Apr. 2011 \\ Published: 05 Oct. 2011 \\ How to cite this article: \\ Boyce, G.D. \& Harris, G., \\ 2011, 'A closer look at racial \\ differences in the reporting \\ of self-assessed health \\ status and related concepts \\ in South Africa', Health SA \\ Gesondheid 16(1), Art. \#559, \\ 9 pages. doi:10.4102/hsag. \\ v16i1.559

\section{Note:} \\ Following common practice, \\ 'Black' refers to Black African \\ persons whilst 'black' refers \\ to Black, Coloured and Indian \\ respondents, that is, the \\ groups collectively referred \\ to as 'non-whites' under \\ apartheid.
}

(C) 2011. The Authors. Licensee: AOSIS OpenJournals. This work is licensed under the Creative Commons Attribution License.
South Africa's populace is characterised by large differences in health, with vast inequalities between members of different groups that can be identified by using a number of tested health indicators, with self-assessed health (SAH) status amongst them. Generally, the average White person's health, however measured, is considerably better than that of Black African persons with the health of Indian and Coloured persons somewhere between the two. Typically, this pattern is attributed to the continued association between race and socio-economic status.

Recent empirical work conducted, however, seems to cast doubt on the validity of the assumption that SAH can be compared directly across members of different groups. In light of this concern, and the challenge which it poses to the interpretation of the results of much current South African empirical work, this article explores possible systematic differences with respect to the perception and reporting of SAH between members of different race groups in South Africa.

Using data drawn from a nationally representative survey of approximately 3000 respondents, this study analysed racial differences in SAH alongside domain-specific SAH and attitudes to a number of health-related areas (e.g. reference groups, perceptions of main influences on health, etc.). The analysis revealed a number of differences when compared to the usual racialised pattern observed. It is held that these differences suggest that there might be a role for race to play in the assessment and reporting of SAH independently of its continued association with socio-economic status.

Suid-Afrikaners word gekenmerk deur groot verskille in die gesondheidsvlakke van die bevolking, met beduidende ongelykhede tussen die verskillende bevolkingsgroepe wat geïdentifiseer kan word met behulp van vele beproefde gesondheidsaanwysers, onder meer self-geassesseerde gesondheid (SAH)-status. Die gemiddelde Wit persoon se gesondheid is, nieteenstaande die maatstaf, aansienlik beter as dié van 'n Swart-Afrikaanse person, met die gesondheid van die Indiër persoon en Kleurling persoon wat êrens tussen die twee groepe lê. Hierdie tendens word tipies toegeskryf aan die voortgesette assosiasie tussen ras en sosiaalekonomiese status.

Onlangse empiriese werk werp egter twyfel op die geldigheid van die veronderstelling dat $\mathrm{SAH}$ van lede van verskillende groepe direk met mekaar vergelyk kan word. In die lig hiervan en die uitdaging wat dit inhou vir die interpretasie van die resultate van ' $n$ baie onlangse Suid-Afrikaanse empiriese studie, ondersoek hierdie artikel moontlike sistematiese verskille met betrekking tot die persepsie en rapportering van SAH tussen mense van verskillende rassegroepe in Suid-Afrika.

Data vanuit ' $n$ nasionale verteenwoordigende opname van ongeveer 3000 respondente is in hierdie studie gebruik. Die studie ontleed hierdie rasseverskille in SAH tesame met die domeinspesifieke SAH asook die gesindhede ten opsigte van 'n aantal van die gesondheidsverwante gebiede (bv. verwysingsgroepe, die persepsies van die belangrikste invloede op gesondheid ens.) Die analise het ' $n$ aantal verskille getoon in vergelyking met die gewone patroon wat op ras gebaseer is. Daar is van mening dat hierdie verskille daarop dui dat ras dalk tog ' $n$ rol speel in die evaluering en rapportering van $\mathrm{SAH}$, ongeag die voortgesette assosiasie met sosiaalekonomiese status.

\section{Introduction}

\section{Background}

South Africa's populace is characterised by large differences in health, with vast inequalities found to exist between citizens using a number of tested health indicators. Health inequalities have been 
observed to exist along racial and socio-economic lines and appear to reflect previous discriminatory policies of racebased exclusion and the award of privilege. Regardless of the health indicator (e.g. life expectancy, under-five mortality and morbidity) used, a generalised pattern to observations exists. White persons' health, however measured, is considerably better than that of Black African persons with the health of Indian and Coloured persons somewhere between the two (Jelsma \& Ferguson 2004; Ramkissoon et al. 2004; Statistics South Africa 2004; Ijumba \& Barron 2005; Desmond \& Boyce 2006). Health differences have also been reported along socio-economic lines, for it was found that citizens of a higher socio-economic status enjoyed better health than their poorer compatriots (Statistics South Africa 2004; Ijumba \& Barron 2005).

\section{Self-assessed health in South Africa}

One subjective measure of health frequently used, nationally and internationally, is self-assessed health (SAH) status. $\mathrm{SAH}$ has been found to be a multifaceted measure that is determined by a number of individual (e.g. age, sex and health behaviours) and societal level determinants (Wilkinson \& Marmot 2003). Of these determinants, a strong positive association has been observed between $\mathrm{SAH}$ and socio-economic status, as measured, for example, by income, occupation and education levels. SAH has been found to be a fairly good predictor of later health outcomes (Idler \& Kasl 1991; Idler \& Benyamini 1997). It is usually reported in response to a question along the lines of, 'In general, how would you rate your health at present?' Answers are then generally given on a 5-point scale ranging from 'very poor' to 'excellent'. A sixth category which allows respondents to reply that they 'Don't know' is usually added as well.

The many studies which have investigated the distribution of SAH in South Africa exhibit the same strong relationship between race and SAH that was described earlier. Typically, this pattern is attributed to the continued association between race and socio-economic status, which is a product of South Africa's long history of inequality and official discrimination on the basis of race, or the psychosocial effects attached to the persistence of attitudes (perceived or real) fostered thereunder. Charasse-Pouèlè and Fournier (2006) and Williams et al. (2008) elaborate on these effects. Evidence of the long-ranging effects of these policies is shown in studies of South Africa's national income distribution which is still notably skewed in favour of White persons (Hoogeveen \& Özler 2005; Statistics South Africa 2007). Studies of access to healthcare reveal similar racial differences (Health Systems Trust 2004; Statistics South Africa 2004). Race, class and socio-economic status in South Africa have an intertwined relationship. Consequently, it becomes relatively straightforward to explain current racial differences in health in terms of the racially stratified distribution of income and the previous government's policy of systematic underinvestment in infrastructure in, and provision of public services to members of, certain communities. According to this view, the relationship between race and health is an artefact of the relationship between race and socio-economic status. Race per se is not driving this relationship.

\section{Problem statement}

Recent international empirical work, however, highlights potential differences between the dimensions of health which inform individuals' assessments and reporting of SAH and 'true' or underlying health (Quesnel-Vallée 2007). Subsequently, the degree to which SAH can be used to measure and to track national trends in health has been questioned (Salomon et al. 2009). These arguments echo earlier misgivings about the potentially misleading policy implications which can be arrived at when using SAH in the evaluation of healthcare interventions (Sen 2002).

Recent studies in this area have also raised several questions about the validity of the implicit assumption that SAH is directly comparable across members of different groups. In particular, several concerns have been raised about the effects of 'reference groups' and 'cultural factors' on respondents' assessment and on the reporting of SAH. For instance, Kuhn, Rahman and Menken (2004) contend that SAH may not be internationally comparable, citing especially the divide between developed and developing countries. Jürges (2004) concludes that SAH is subject to reference group effects, where reference groups are delineated along age, sex and income lines. Based on these findings, he argues that systematic differences in the reporting of SAH across groups may markedly bias the conclusions that can be drawn from studies that investigate the distribution of SAH across different groups of respondents. He even proceeds to recommend that SAH be compared only within specific subsamples where reporting styles are similar across respondents (Jürges 2004:11). Jürges (2007) supports this assertion with cross-national data from a survey run across 10 European countries. The data illustrate how explicit control for cross-cultural differences in reporting styles affects the size of the estimated average inter-country health differences, and the relative ranking of countries according to the reported health levels of citizens (Jürges 2007). The conclusions with regard to 'reference groups' are supported by Ahn (2003), who contends that culture and the social environment play an important role in the formation of responses to questions about SAH. The net effect of this work is that the appropriateness of intra-group comparisons of SAH has been questioned in many instances.

Arguably, the validity of the assumption that SAH of members of different groups can be compared, directly influences the inferences that can be made about the nature of the relationships between reported $\mathrm{SAH}$, race and socioeconomic status that exist in South Africa and were described earlier. Moreover, given the increasing use of this indicator in policy design, biases in its assessment and reporting are likely to complicate the targeting and evaluation of healthcare policy. There is thus a weakness in one of the tools available to policymakers to make decisions on the allocation of scarce resources to intended beneficiaries who are identified on the basis of need. The use of a flawed indicator, without taking steps to remedy its weaknesses, might compromise the achievement of greater health equity in future. The 
consequences thereof are likely to be magnified in a society as diverse as South Africa.

Importantly, these difficulties are present whether the state is aware of the incomparability of this measure across members of these two communities or not. By way of example, consider the situation of a population which consists of two communities, A and B, where members of Community A appeal to a higher level of idealised health than members of Community B when constructing their notions of health, that is, members of Community B are likely to be satisfied with a lower level of health than members of Community A. Should perceptions of healthiness influence the health levels to which persons aspire, one would presume that the average (true or underlying) health of members of Community A would be better than those of Community B in future. This could occur through either a greater likelihood of these citizens adopting more protective health behaviours, proactive health-seeking behaviour, their greater demands upon the state for better access to healthcare facilities and so forth. Regardless of the channels through which this occurs, SAH would mask differences in underlying health between members of these two communities if assessment and reporting patterns remain unchanged.

If the government is aware of the differential assessment of $\mathrm{SAH}$, it is confronted with the dilemma of which level of optimal health, that of Community A or that of Community $B$, to set as a target for the average citizen by bearing in mind that equity considerations often prevent the state from providing services at differential levels to individuals which could be considered to be more consistent with the health perceptions of the groups to which they belong. Setting one level of health as a goal for both communities means that the state effectively under-supplies or over-supplies healthcare provision, depending on which community's perception of optimal health or healthiness it uses as a benchmark for all citizens to achieve or maintain or both. Both the under-supply and the over-supply of healthcare, relative to perceptions of healthiness, that is, hold implications for the state's ability to achieve its other developmental goals.

On the other hand, if the state is unaware of differences in health perceptions across communities and their effect on the reporting of $\mathrm{SAH}$, it risks the possibility of fomenting health inequalities between groups. Returning to the stylised aforementioned example, consider that a person drawn from Community A, whose members generally appeal to a higher standard of health when reporting their SAH, will be more likely to report poorer health than a comparable person from Community B, that is, ceteris paribus. If this relationship held on average and if the state aimed to equalise the distribution of SAH between the two communities, the implementation of $\mathrm{SAH}$ as a guide to resource allocation would suggest that it ought to direct more efforts towards improving the health of members of Community A. If it does so, it would ultimately increase health inequalities within the country.

\section{Research objectives}

In light of the biases associated with the use of SAH for comparative purposes and the potential dangers associated with these biases, this study attempts to explore systematic differences with respect to the reporting of SAH in South Africa between members of different racial groups. This will be conducted by investigating the racial distribution of $\mathrm{SAH}$ and number of aspects related to it, such as SAH in a number of domains (e.g. vision and hearing) and attitudes to a number of health-related areas (e.g. the existence of reference groups relative to whose members respondents rate their SAH, perceptions of the main influences on health, etc.), which might provide insight into the way that respondents construct their notions of 'health' and thence influence their reporting behaviour when assessing and reporting their SAH. Where racial differences are found, possible reasons for their existence will be advanced wherever possible. Thereafter, implications for the validity of the assumption that SAH can be used as a measure when comparing interracial health levels in South Africa will be discussed.

Two inherent weaknesses in this approach are worth noting. Firstly, concentrating exclusively on interracial group differences in the reporting of SAH could be considered a shortcoming as, in practice, there are likely to be many other potential influences, for example, age group, sex, education and class, which could exert an even greater influence on respondents' reporting behaviour. Another limitation is that differences between subgroups of respondents (e.g. differences in health assessments between black men and black women or White rural dwellers and White urban dwellers) will not be investigated. In defence of this decision, it should be noted that small sample sizes frequently preclude this type of analysis in practice.

\section{Contribution to the field}

By exploring potential biases in the manner in which persons of different races assess and report upon their subjective health, status researchers and policymakers alike will be enabled to contextualise reported differences in SAH. This in turn will grant greater insight into the distribution of 'true' or underlying health in South Africa. This exploratory study has been undertaken in recognition of the important contribution which an investigation of this sort could make.

\section{Research method and design Design}

SASAS (South African Social Attitudes Survey) is based on the administration of a closed-ended questionnaire during a face-to-face interview by a trained fieldworker. It is divided into a series of modules, each designed to elicit information on a number of social and demographic variables and attitudes.

The analysis in this article is based on respondents' answers to 17 of the 30 questions which make up the Health Module of the questionnaire. The module itself was designed specifically 
for the purposes of this study. Most questions relied on Likert-scale-type responses with five discrete response categories ranging from 'excellent' through to 'very poor' with a separate category for 'Don't know'. A few questions did not offer any response guidelines to respondents and answers consisted solely of the information proffered by respondents. In these cases, responses were grouped to discern patterns in the raw data.

\section{Materials}

The data for this study was taken from the 2008 wave of the Human Sciences Research Council's South African Social Attitudes Survey (SASAS) data set.

\section{Data analysis}

Data was analysed using quantitative data analysis techniques. All analyses were carried out using the STATA ${ }^{\circledR}$ statistical software package (version 10). Given the categorical nature of responses, the Chi-squared test was used to test for any significant statistical differences between the responses of members of different groups. In the discussion that follows, differences have been reported using significance levels of $10 \%, 5 \%$ and $1 \%$. All the analyses take weighting and stratification effects into account.

\section{Context of the study}

The current study is a desktop-based analysis of the data collected in SASAS, a national survey of the attitudes of a sample of approximately 3000 randomly selected South Africans aged 16 and older. Readers are referred to the technical appendix in Pillay, Roberts and Rule (2006) for a detailed description of SASAS data collection methodology. The sample consists of 1834 Black persons, 480 Coloured persons, 279 Indian persons and 310 White persons, and 1716 women and 1187 men. It is designed to be nationally representative and is weighted by both municipal ward (cluster) and province (strata) (Table 1)

\section{Results}

\section{The distribution of current self-assessed health and other subjective indicators of health}

The analysis is introduced with a description of the racial distribution of SAH (Table 2) which illustrates the predictable marked racial pattern to $\mathrm{SAH}$ that was highlighted earlier. It can be seen that Black and Coloured respondents report generally lower levels of health than their White and, to a lesser extent, Indian compatriots. When tested, racial differences were significant at the 5\% level using a Chisquared test.

In addition, respondents were asked whether they experienced any health conditions that either impeded their enjoyment or quality of life, or interfered with their movement or functioning in daily activities. A minority of respondents reported that they did experience these problems (Table 3).

\section{Subjective assessments of health in specific domains}

Respondents were then required to assess their $\mathrm{SAH}$ in five specific domains (vision, hearing, mobility, mental health and weight). If race and health were related solely via the historical association between race and socio-economic status and its enduring legacy, one might presume that the distribution of self-reported responses in specific health domains would follow similar patterns to that exhibited in the distribution of SAH when broken down by race.

The percentage of respondents who rated their health in the following domains as either good or excellent broken down by race, were recorded (Table 4). It should be pointed out that no information was gathered on whether respondents had any aids to assist them in their functioning in these areas. It is thus possible that the responses reflect a combination of respondents' perceptions of health in this domain as well as their perceptions of any actual limitations imposed on their functioning or quality of life as a result of any difficulties. This latter effect may well be mitigated by the employment

TABLE 1: Provincial distribution of sample respondents $(N=2904)$

\begin{tabular}{ll}
\hline Province & $\boldsymbol{n}$ \\
\hline Eastern Cape & 318 \\
Free State & 322 \\
Gauteng & 320 \\
KwaZulu-Natal & 485 \\
Limpopo & 365 \\
Mpumalanga & 297 \\
Northern Cape & 277 \\
North West Province & 208 \\
Western Cape & 312 \\
South Africa & $\mathbf{2 9 0 4}$ \\
\hline
\end{tabular}

Source: Authors' original data

$n$, number of respondents; $N$, total number of survey respondents.

Readers are referred to the technical appendix in Pillay, Roberts and Rule (2006) for a detailed description of SASAS data collection methodology.

TABLE 2: The distribution of self-assessed health by race $(N=2881)$.

\begin{tabular}{lccccc}
\hline $\begin{array}{l}\text { Self-assessed } \\
\text { health status } \dagger\end{array}$ & Black & Coloured & Indian & White & Total \\
\cline { 2 - 6 } & 21 & 25 & 37 & 39 & 24 \\
\hline Excellent & 42 & 41 & 35 & 41 & 42 \\
Good & 22 & 20 & 20 & 13 & 21 \\
Average & 11 & 9 & 6 & 6 & 10 \\
Poor & 4 & 5 & 2 & 1 & 3 \\
Very poor & $\mathbf{1 0 0}$ & $\mathbf{1 0 0}$ & $\mathbf{1 0 0}$ & $\mathbf{1 0 0}$ & $\mathbf{1 0 0}$
\end{tabular}

Source: Authors' original data

$N=2881$ respondents.

$\dagger$, Significant at $5 \%$ level.

TABLE 3: Health imposed limitations $(N=2888)$.

\begin{tabular}{lccccc}
\hline $\begin{array}{l}\text { Health imposed } \\
\text { limitation }\end{array}$ & Black & Coloured & Indian & White & Total \\
\cline { 2 - 6 } & 22 & 17 & 12 & 13 & 20 \\
\hline $\begin{array}{l}\text { Limit your } \\
\text { movement or daily } \\
\text { functioning } \dagger\end{array}$ & 24 & 19 & 13 & 11 & 22 \\
$\begin{array}{l}\text { Interfere with } \\
\text { quality of life }\end{array}$ & & & & & \\
\hline
\end{tabular}

Source: Authors' original data

$N=2888$ respondents.

$\uparrow$, Significant at $5 \%$ level.

, Significant at $5 \%$ level.
\pm , Significant at $1 \%$ level. 
of certain aids such as spectacles, wheelchairs and so forth. It is also possible that the availability of these aids may vary across different groups in the population.

In contrast to the distribution of overall SAH, a statistically significant difference at the $1 \%$ level is only reported in one of the domains: mobility. The only other significant difference reported, is for vision, which is significant at the $10 \%$ level.

\section{Trajectories of self-assessed health}

A reduction and/or elimination of racial effects are also apparent in respondents' retrospective evaluations of SAH (Table 5). Regarding the trajectories in SAH over the previous year, it is indicated that whilst White respondents still recall relatively higher prior levels of $\mathrm{SAH}$, racial differences are now no longer significant at the $1 \%$ level but only at the $10 \%$ level (Table 5). There are also no significant racial differences in retrospective evaluations of health 5 years previously (Table 4). The proportion of White respondents that reported good or excellent health remained largely stable whilst that of black respondents generally deteriorated over the 5-year recall period. In addition, there were fluctuations between respondents of different races, with between $8 \%$ and $13 \%$ more reporting good or excellent health earlier.

\section{Reference groups}

As stated earlier, a factor which has been argued to influence reporting styles is that of reference group effects (Ahn 2003; Jürges 2004). To reiterate, the existence of reference groups against which respondents can measure or compare their health has generated much debate about whether selfreported responses are directly comparable. In order to explore whether racial differences in the choice of reference groups might account for the inconsistencies in the effect of race on the reporting of subjective health (global or domainspecific), respondents in the SASAS were asked to describe the reference groups against whose members they compared their health.

Results show significant racial differences amongst those respondents who reported knowing to whom they compared their health (Table 6). Differences appear to be driven by the responses to whether respondents compared their health to those of friends and family, or those with whom respondents have some contact and interact with in some way (neighbours, co-workers or other gymnasium members). Whilst family and friends were by far the most popular choice amongst all respondents, White and Indian respondents were much more inclined to choose them. It should be noted that reporting similar reference groups does not imply that the underlying populations against which respondents compare their health are the same. For instance, the population of family members will differ between respondents and with it the health of members of this group. Finally, only respondents' first responses to the question about reference groups were recorded. This means that only simply-defined or onedimensional reference groups are described. Such simple reference groups are unlikely to apply in practice (Deaton 2002; Ahn 2003).

\section{General attitudes to health}

The next part of the analysis explored respondents' levels of agreement with certain statements about health. Each statement was designed to elicit information on some underlying belief about health. Their inclusion in the analysis is based on the premise that the underlying beliefs or attitudes about health which a respondent holds might provide insights into behaviours which affect health.

Two striking observations about the data (Table 7) presented should be pointed out. One is the low percentage of respondents (roughly between $0.5 \%$ and $4 \%$ for individual statements) who reported Don't Know as their answer to any of the questions below. The second is the low percentage (roughly $9 \%$ of all responses including those who 'Don't $k n o w$ ') of respondents who reported that they neither agreed nor disagreed with each of these statements. This high degree of certainty was unexpected given the attitudinal nature of the questions.

For the statement 'You can never be too thin', White persons' responses were significantly different from those of other

TABLE 4: Self-assessments of health in specific domains $(N=2885)$.

\begin{tabular}{lccccc}
\hline Domain & \multicolumn{5}{c}{$\mathbf{\%}$} \\
\cline { 2 - 6 } & Black & Coloured & Indian & White & Total \\
\hline Overall† & 64 & 66 & 72 & 81 & 66 \\
Vision $\ddagger$ & 80 & 79 & 67 & 85 & 80 \\
Hearing & 88 & 87 & 92 & 88 & 88 \\
Mobility $\dagger$ & 83 & 83 & 90 & - & 85 \\
Mental health & 82 & 84 & 91 & 90 & 83 \\
Weight & 81 & 74 & 84 & 80 & 81 \\
\hline
\end{tabular}

Source: Authors' original data

$N=2885$ respondents.

$N=2885$ respondents.
$\dagger$, Significant at $1 \%$ level.

$t$, Significant at $1 \%$ level.
S

TABLE 5: Retrospective health evaluations $(N=2858)$

\begin{tabular}{lccccc}
\hline Period & \multicolumn{5}{c}{$\%$} \\
\cline { 2 - 6 } & Black & Coloured & Indian & White & Total \\
\hline Current $\dagger$ & 64 & 66 & 72 & 81 & 66 \\
1 year ago $\$$ & 72 & 70 & 74 & 80 & 73 \\
5 years ago & 74 & 74 & 85 & 81 & 75 \\
\hline
\end{tabular}

Source: Authors' original data

$N=2858$ respondents.

$\dagger$, Significant at $1 \%$ level.

$\star$, Significant at $10 \%$ level.

TABLE 6: Reference groups with whom respondents compared their health $(N=2776)$.

\begin{tabular}{lccccc}
\hline Reference Group & \multicolumn{5}{c}{$\%$} \\
\cline { 2 - 6 } & Black & Coloured & Indian & White & Total \\
\hline Family and friends & 47 & 47 & 64 & 65 & 50 \\
$\begin{array}{l}\text { Neighbours, } \\
\text { co-workers or } \\
\text { other gymnasium } \\
\text { members }\end{array}$ & 19 & 26 & 10 & 10 & 19 \\
$\begin{array}{l}\text { Persons of similar } \\
\text { age or the same } \\
\text { sex or income }\end{array}$ & 28 & 23 & 23 & 16 & 26 \\
$\begin{array}{l}\text { Other citizens, } \\
\text { persons on TV or } \\
\text { in magazines }\end{array}$ & 5 & 4 & 3 & 10 & 6 \\
\hline $\begin{array}{l}\text { Source: Authors' original data } \\
N=2776 .\end{array}$ & & & & \\
,+ Significant at $1 \%$ level. & & & & & \\
\hline
\end{tabular}


race groups with roughly $60 \%$ of White respondents strongly disagreeing with this statement. Conversely, black respondents tended to support the notion that one can never be too thin.

The only other statistically significant difference was in the percentage of respondents who agreed or strongly agreed that richer people are healthier people. The percentage of respondents that agreed that richer people are healthier was $31 \%$. Black respondents were more likely to feel that richer people were healthier people than respondents of other races. Their responses were significantly different from those of other races. The responses of Indian respondents were also significantly different from those of respondents of other races. Just $4 \%$ of Indian respondents agreed or strongly agreed with this statement. The responses of Coloured (20\%) and White $(11 \%)$ respondents were not significantly different from each other.

\section{Understanding of the concept of 'health'}

Respondents were subsequently asked to define their concept of 'health'. In order to explore respondents' understanding of health, respondents were asked, 'What do you think of when thinking about health?' Respondents' first, second and third responses to this question were recorded. It is important to note that answers were not dependent upon prompting on the part of the interviewer; the interviewer merely recorded up to a maximum of three responses in the order in which respondents provided them. Each of their three responses was then grouped into one of five categories namely:

1. conditions requiring medical diagnosis

2. visible physical ailment

3. observation

4. health behaviours or

5. an 'Other' category, for those responses that could not be neatly classified into one of the categories mentioned earlier.

An overall indicator was created from these coded responses. This variable took on the same five values as respondents' three coded responses. Scoring was carried out by assigning respondents to the category into which at least two of their three responses were coded, that is, where two or more responses were from one category. It follows that if a respondent reported that they thought of physical ailments as their first two responses and gave for instance a healthbehaviour as their third response, this respondent would be reported as thinking predominantly about physical ailments when considering health and this value would be assigned on the overall indicator. If their responses displayed no clear pattern, that is, if each of their three responses was from a different category, their score on the overall indicator was categorised in a sixth category, namely combination of factors.

The distribution of the overall indicator is broken down by race (Table 8 ). Overall, it can be seen that respondents thought predominantly about conditions that required a medical diagnosis when thinking about their health (Table 8). This was the most popular category after a 'combination of factors' (see Column 6). Visual inspection was the next most popular category. Although there was some variation in the responses of members of different race groups, these differences were not statistically significant at traditional testing levels.

\section{Ethical considerations}

Ethical approval for this study was obtained from the Human Sciences Research Council's Ethics Committee. The data collection for the actual survey upon which data results are based was also subject to approval by this committee. This approval provides guidelines on fieldwork related issues such as informed consent, confidential storage of raw data and so forth.

\section{Validity and reliability}

Although reliability was not explicitly estimated, it should be pointed out that the SASAS survey instrument was pilot tested before being rolled out nationally. In addition, the Health Module relied heavily on the use of standard test measures (e.g. SAH) and reporting methods which have been widely used and tested in related empirical work.

In terms of internal validity, it is pointed out that although $\mathrm{SAH}$ has been found to be a good predictor of later health outcomes such as mortality and morbidity (Idler \& Kasl 1991; Idler \& Benyamini 1997), the components of SAH have been debated since it first began to be widely used in survey research, as seen in an early summary by Okun et al. (1984),

TABLE 7: Respondents who agree and/or strongly agree with various statements about health $(N=2780)$.

\begin{tabular}{lccccc}
\hline Statement & \multicolumn{5}{c}{$\mathbf{\%}$} \\
\cline { 2 - 6 } & Black & Coloured & Indian & White & Total \\
\hline $\begin{array}{l}\text { Overweight people } \\
\text { are unhealthy }\end{array}$ & 47 & 47 & 64 & 65 & 50 \\
$\begin{array}{l}\text { You can never be } \\
\text { too thin† }\end{array}$ & 58 & 48 & 55 & 28 & 54 \\
$\begin{array}{l}\text { You are as healthy } \\
\text { as you feel }\end{array}$ & 76 & 79 & 86 & 77 & 77 \\
$\begin{array}{l}\text { Richer people are } \\
\text { healthier people } \dagger\end{array}$ & 37 & 20 & 4 & 11 & 31 \\
$\begin{array}{l}\text { If you worry you } \\
\text { die; if you do not } \\
\text { worry you die }\end{array}$ & 65 & 71 & 65 & 59 & 65 \\
\hline
\end{tabular}
worry you die

Source: Authors' original data

$N=2780$ respondents.

$\dagger$, Significant at $1 \%$ level.

TABLE 8: What do you think about when considering 'health' $(N=2808)$.

\begin{tabular}{lccccc}
\hline Category & \multicolumn{5}{c}{$\%$} \\
\cline { 2 - 6 } & Black & Coloured & Indian & White & Total \\
\hline $\begin{array}{l}\text { Conditions } \\
\text { requiring diagnosis }\end{array}$ & 29 & 21 & 28 & 23 & 27 \\
$\begin{array}{l}\text { Visible physical } \\
\text { ailment }\end{array}$ & 22 & 34 & 15 & 28 & 24 \\
$\begin{array}{l}\text { Observation } \\
\text { Health behaviours }\end{array}$ & 3 & 3 & 2 & 3 & 3 \\
$\begin{array}{l}\text { Other } \\
\begin{array}{l}\text { Combination of } \\
\text { factors }\end{array}\end{array}$ & 14 & 11 & 12 & 12 & 14 \\
\hline
\end{tabular}

Source: Authors' original data

$N=2808$ respondents. 
and scholars probably will continue to investigate in the foreseeable future.

External validity of results is ensured through SASAS's research design. As mentioned, SASAS 2008 is a nationally representative survey of a sample of approximately 3000 randomly selected South Africans aged 16 and older. All analyses make use of weights that take stratification (by province) and clustering (by municipal ward) effects into account.

\section{Discussion \\ Outline of the results}

To reiterate, this research set out to explore racial differences in the reporting of $\mathrm{SAH}$ and several related subjective health indicators in South Africa. The next section of the article discusses results where racial effects were found to be statistically significant in terms of prior findings that demonstrate a consistent pattern to the relationship between race and SAH. According to studies (Statistics South Africa 2004; Desmond \& Boyce 2006) which report these findings that were cited earlier, White persons enjoy better health on average than black persons.

\section{The distribution of current assessments of health and other subjective indicators of health}

The distribution of SAH reveals the existence of a racial pattern to responses. The results presented in Table 2 and Table 3 suggest that, by and large, Black and Coloured respondents enjoy much lower levels of health than their White and Indian counterparts.

\section{Subjective assessments of health in specific domains}

The comparison of the distribution of reported selfassessments of health in specific domains (Table 4), however, portrays a murkier picture than that portrayed in the distribution of overall SAH. These results suggest that race is not as strongly associated with the reporting of health in these specific domains as it is with the reporting of overall $\mathrm{SAH}$. This raises an important question, 'How does one reconcile these observations with the results, with respect to SAH and the findings of prior studies?' In other words, if the relationship between race and SAH is solely a function of socio-economic status, how is it possible that race is found to be unrelated to assessments of health in some domains, domains which can be considered as sub-components really, of overall health? Surely, if socio-economic status was the only channel through which race and SAH was related, response patterns and their associated differences in most domains would be similar to that observed in the distribution of SAH or any other global type measure.

Relying on conjecture alone, a number of explanations of these results could be put forward. The most simple of these is that, in spite of the ample evidence available which highlights the disproportionate disease burden borne by the poor (Feinstein 1993; Judge \& Paterson 2001; Deaton 2002), no association between socio-economic status and subjective health could exist in certain health domains. From the close relationship between race and socio-economic status, it follows that there are no significant racial differences in these domains. Allowing for the possibility that SAH is subject to cultural or racial influences is another possible explanation. More specifically, the possibility that race and reported SAH in South Africa might be related via channels other than socio-economic status or the lasting effects of past racist policies might help to reconcile the two sets of analyses mentioned earlier. In particular, the absence of marked racial effects in the reporting of health in certain domains might allude to the possibility that respondents of different races appeal to different standards in such reporting. For instance, if the underlying distribution of good or excellent vision (objectively measured) was the same across the population but Black persons appealed to lower standards and White persons to higher standards in the self-reporting of their vision, then Black persons' self-reported responses will be biased upwards and White persons' responses downwards. If the situation described earlier was applicable, racial differences in the reporting of assessments in this area would either be reduced or possibly eliminated in the case where true underlying vision (objectively measured) was higher for White persons than for Black persons. Notwithstanding this speculation, it should be clear that no firm conclusions can be reached in the absence of information on exactly how respondents of different races form their benchmarks or reference points when assessing and reporting upon their domain-specific health.

\section{Trajectories of self-assessed health}

Turning to retrospective evaluations of SAH (Table 5), one is inclined to suspect that reported retrospective evaluations which do not display any racial effects are anomalies. Alternatively it could be at least some evidence which demonstrates that respondents of different races tend to assess, recall and report their subjective health differently given the wealth of local and national level studies which confirm the persistence of racial patterns in the reporting of current SAH and other health measures in South Africa.

Disregarding the situation where differences in the average health of black respondents relative to that of White respondents only arose during the previous five year period, how might results be influenced by differences, if any, in race-based reporting styles? Firstly, it could reflect some influence of state dependence on recall by respondents. Assume that those who are in relatively poorer health states at present tend to over-estimate their health previous status. As those who are in poorer health now are predominantly black, this could account for black responses of prior health being 'inflated' relative to current health. Related to this account, differences might also be driven by the manner in which respondents recall and report upon prior events. For example, it has been argued that retrospective evaluations of health and well-being in general are frequently dominated by the recall of a usually severe reference point or bout of 
negative health status (Hillen et al. 2000; Siegrist 2003). Given observed racial patterns to morbidity and mortality levels in SA (Ijumba \& Barron 2005), black respondents are more likely to have experienced a negative health event than White respondents during the past year. Therefore, even if current levels of health status between respondents of different races were the same, they might report relatively higher levels of retrospective SAH than White respondents on average given the greater likelihood that their assessments are being benchmarked against a negative event in the recent past.

Secondly, there may be a differential age effect at play amongst members of different race groups. The following contrived example illustrates how this differential age effect could lead to the observed pattern to responses. Assume that all respondents benchmark their assessments of current $\mathrm{SAH}$ relative to those of similar age, that is, there is an agebased reference group effect. Additionally, assume that black respondents, when recalling their previous health states, do so relative to their health now or relative to the health of those who are now of similar age. By doing so, they are using the same standard to form current and past health assessments. Assume that White respondents, on the other hand, base their assessments of previous health states upon the health of those who are now of similar age to their younger selves. By doing so, they are allowing for the possibility that the target health levels or the standards by which health is measured ought to be different for persons of different ages. Accounting for age effects in this way could possibly lead to a 'softening' of their health assessments as they age. Subject to the deterioration in health which is presumed to accompany the ageing process, it is easy to see how the differential manner in which respondents form their assessments of health may affect the reported responses of black versus White respondents in this situation. It is worthwhile to note that this can arise without having to make any assumptions about true movements in the underlying distribution of health in each race group over the intervening period.

\section{General attitudes to health: Richer people are healthier people}

The discussion concludes by highlighting racial differences in responses to the statement, 'Richer people are healthier people'. Emphasis has been placed on this statement given the tendency to attribute the observed relationship between race and SAH in South Africa to the continued relationship between race and socio-economic status.

At first glance, the percentage of respondents that reported either agreeing or strongly agreeing with this statement (see Table 7, Row 5) appears to be somewhat low relative to the well-established link between income and health (Goldman 2001; Adler \& Newman 2002). Tentatively, this result might suggest that the pathways through which respondents perceive wealth or socio-economic status to be associated with health status might not be as apparent as the evidence of the actual link between the two that has been gleaned from aggregated data.
Breaking results down by race also masks some facts about the racialised distribution of national income that might contextualise respondents' views on the link between health and income. Recall that the average Indian or White respondent is likely to enjoy a higher level of socio-economic status than the average Black respondent. Thus, finding that respondents from these groups are less likely than Black respondents to feel as strongly that income and health are related implies that richer people are less likely to feel that they are healthier than others. Assuming that persons who enjoy different levels of socio-economic status subscribe to similar notions of health when responding (i.e. assessments are comparable), this could mean one of two things. Respondents might concentrate on the causation which runs from income to health when replying. If so, results could suggest that poorer respondents over-estimate the perceived benefits of increased income or richer people tend to be more reserved in their assessment of the health benefits which income can confer. Alternatively, richer people might not want to believe that their wealth confers health benefits on them and instead concentrate on the causation that runs from health to income when responding. If so, perhaps responses to the statement 'Healthier people are richer people' would have allowed a truer assessment of their views on the healthincome relationship than the statement 'Richer people are healthier people' which was used in SASAS.

\section{Limitations of the study}

Although run annually, SASAS is not a longitudinal study. Each annual survey is run independently and, besides certain core modules, there is no guarantee that specific modules will be run in consecutive years or in any subsequent year for that matter. Consequently, the data collected from any annual SASAS are cross-sectional in nature and subject to all the limitations imposed by this type of data. Furthermore, as SASAS is a generalised survey instrument that is designed to gather information on a wide range of attitudes, its usefulness in exploring any particular attitude in great depth is limited.

\section{Conclusion}

Using descriptive statistics based on data taken from a recent nationally representative survey (SASAS 2008), this article found evidence in support of the hypothesis that health, as measured by SAH, and race are related. The distribution of SAH was largely consistent with prior South African studies which found race-related differences in health (Statistics South Africa 2004; Charasse-Pouèlè \& Fournier 2006). The analysis of the relationships between race and related subjective health indicators (such as retrospective health assessments, assessments of health in specific domains) on the other hand did not exhibit such clear-cut patterns when compared to the distribution of SAH. Racial differences were either reduced or were not statistically significant for these indicators. Furthermore, there were racial differences in reported reference groups, the groups against whose members' respondents compare their health when assessing and reporting upon their SAH and in some general attitudes to health. 
Given the exploratory nature of this study, and limitations in the data which it is based upon, it is difficult to attach much strength to the conclusions which can be drawn from these findings. Nonetheless, they are likely to add an element of uncertainty to the debate about the underlying causes of the observed relationship between race and SAH. This raises the possibility that there might be a role for race, or other factors associated therewith, to play in the assessment and reporting of SAH independently of its continued association with socio-economic status. In particular, as some of these effects might bear upon the response styles of respondents, and the notions by which they construct their assessments of health, they may arguably even cast some doubt on the appropriateness of comparisons of SAH across members of different race groups.

In light of this assertion, it is recommended that further detailed work be undertaken into testing the validity of the assumption that SAH can be compared across members of the four major race groups in South Africa.

\section{Acknowledgements}

The authors would like to acknowledge the financial support of South Africa's Medical Research Council which provided a grant that made possible the purchase of the Health Module in the 2008 wave of the Human Sciences Research Council's South African Social Attitudes Survey (SASAS).

\section{Competing interests}

The authors declare that there were no competing interests in the writing of this article.

\section{Authors' contributions}

G.B. was responsible for the primary data analysis and the initial write-up of the article. G.H. contributed to the interpretation of results and the write-up of the discussion thereof

\section{References}

Adler, N. \& Newman, K., 2002, 'Socio-economic Disparities In Health: Pathways and Policies', Health Affairs 21(2), 60-76. doi:10.1377/hlthaff.21.2.60, PMid:11900187

Ahn, N., 2003, 'Assessing Self-Assessed Health Data', working paper no. 200224R, Fundación de Estudios de Economía Aplicada (FEDEA).

Charasse-Pouèlè, C. \& Fournier, M., 2006, 'Health disparities between racial groups in South Africa: A decomposition analysis', Social Science and Medicine 62, 28972914.

Deaton, A., 2002, 'Policy Implications of the Gradient of Health and Wealth', Health Affairs 21(2), 13-30. doi:10.1377/hlthaff.21.2.13, PMid:11900153
Desmond, C. \& Boyce, G., 2006, 'A healthy attitude?', in U. Pillay, B. Roberts \& S. Rule (eds.), South African Social Attitudes Changing Times Diverse Voices, pp. 200-221, HSRC Press, Cape Town.

Feinstein, J.S., 1993, 'The Relationship between Socio-economic Status and Health: A Review of the Literature', The Milbank Quarterly 71(2), 279-322. doi:10.2307/3350401, PMid:8510603

Goldman, N., 2001, 'Social Inequalities in Health: Disentangling the Underlying Mechanisms', paper presented at Demography and Epidemiology: Frontiers in Population Health and Aging Conference, Georgetown University.

Health Systems Trust, 2004, 'The Second Equity Gauge Monitoring Fairness in Access to Basic Services Essential for Health', Report, Health Systems Trust, Durban.

Hillen, T., Schaub, R., Hiestermann, A., Kirschner, W. \& Robra, R.P., 2000, 'Self rating of health is associated with stressful life events, social support and residency in East and West Berlin shortly after the fall of the wall', Journal of Epidemiology and Community Health 54, 575-580. doi:10.1136/jech.54.8.575

Hoogeveen, J. \& Özler, B., 2005, 'Not Separate, Not Equal: Poverty and Inequality in Post-Apartheid South Africa', working Paper, William Davidson Institute, University of Michigan.

Idler, E. \& Benyamini, Y., 1997, 'Self-rated health and mortality: A review of twentyseven community studies', Journal of Health and Social Behaviour 38(1), 21-37. doi:10.2307/2955359, PMid:9097506

Idler, E. \& Kasl, S., 1991, 'Health perceptions and survival: Do global evaluations of health status really predict mortality?', Journal of Gerontology 46(2), S55-S65.

Ijumba, P. \& Barron, P., 2005, 'South African Health Review 2005', Health Systems Trust, Durban.

Jelsma, J. \& Ferguson, G., 2004, 'The determinants of self-reported health-related quality of life in a culturally diverse South African community', Bulletin of the World Health Organization 82(3), 206-212. PMid:15112009, PMCid:2585936

Judge, K. \& Paterson, I., 2001, 'Poverty, Income Inequality, and Health', working paper no. 01/29, New Zealand Treasury, Commonwealth Government, Wellington.

Jürges, H., 2004, 'Self-assessed health, reference levels, and mortality', discussion paper no. 0457, Mannheim Research Institute for the Economics of Aging (MEA) University of Mannheim.

Jürges, H., 2007, 'True health vs Response Styles: Exploring cross-country differences in self-reported health', Health Economics 16, 163-178. doi:10.1002/hec.1134, PMid:16941555

Kuhn, R., Rahman, O. \& Menken, J., 2004, 'Survey Measures of Health: How Well do Self-reported and Observed Indicators Measure Health and Predict Mortality?', paper presented at the Workshop on Aging in Africa, University of the Witwatersrand, Johannesburg, South Africa.

Okun, M.A., Stock, W.A., Haring, M.J. \& Witter, R.A. 1984, 'Health and subjective well-being: A meta-analysis', The International Journal of Aging and Human Development 19(2), 111-132. doi:10.2190/QGJN-0N81-5957-HAD

Pillay, U., Roberts, B. \& Rule, S. 2006, 'Appendix 1: Technical details of the survey', in U. Pillay, B. Roberts \& S. Rule (eds.), South African Social Attitudes Changing Times Diverse Voices, pp. 296-300, HSRC Press, Cape Town.

Quesnel-Vallée, A., 2007, 'Self-rated Health: Caught in the crossfire of the quest for "true" health", International Journal of Epidemiology 36(6), 1161-1164.

Ramkissoon, A., Kleinschmidt, I., Beksinska, M. Smit, J., Hlazo, J. \& Mabude, Z., 2004 'National Baseline Assessment of Sexually Transmitted Infection and HIV services in South African public sector health facilities 2002/2003', Summary Report, Reproductive Health Research Unit, University of the Witwatersrand.

Salomon, J.A., Nordhagen, S, Oza, S. \& Murray, C.J.L., 2009, 'Are Americans Feeling Less Healthy? The Puzzle of Trends in Self-rated Health', American Journal of Epidemiology 170(3), 343-351. doi:10.1093/aje/kwp144, PMid:19564169, PMCid:2714952

Sen, A., 2002, 'Health: Perception versus observation', British Medical Journal 324, 860-861.

Statistics South Africa, 2004, 'Perceived health and other health indicators in South Africa', Report, Pretoria: Statistics South Africa. doi:10.1136/bmj.324.7342.860, PMid:11950717, PMCid:1122815

Statistics South Africa, 2007, 'Income and expenditure of households 2005/2006 Analysis of results', Statistical Release P0100, Statistics South Africa, Pretoria.

Wilkinson, R. \& Marmot, M., 2003, Social determinants of health: The solid facts, 2nd edn., World Health Organization (Europe), Geneva.

Williams, D.R., Gonzalez, H.M., Williams, S., Mohammed, S.A., Moomal, H. \& Stein D.J., 2008, 'Perceived Discrimination, Race and Health in South Africa', Social Science \& Medicine 67(3), 441-452. doi:10.1016/j.socscimed.2008.03.021 